SAD / JSR

Sosyoloji Araştırmaları Dergisi / Journal of Sociological Research

Cilt / Volume 20 Say1 / Number 2 (Ekim / October 2017) : (152-172)

\title{
SOCIOLOGICAL EXAMINATION OF EDMUND BURKE'S WORK TITLED "THOUGHTS ON THE REVOLUTION IN FRANCE"
}

M. Zeki DUMAN ${ }^{1}$

\section{ABSTRACT}

Undoubtedly, one of the most important events that deeply affected the Western world and led to historical breakdowns and social changes especially in continental Europe, are the democratic bourgeois revolution took place in France in 1789. Debate and criticism that take place in the academic world in general about revolutions and especially about French Revolution can be evaluated in two segments. On the one hand stand those supporting idea that this struggle launched in the name of humanity promoted progress, enlightenment, human rights and freedom, on the other hand those support idea that with revolution property and rights are seized, ethical and religious values that hold the institutions of society and society together are eliminated and Jacobinism and radicalism were promoted. One of those supporting this claim is Edmund Burke, who is also the subject of this article and who stood with his hard attitude towards the French Revolution during his lifetime. This article, which examines Burke's ideas about the revolution in terms of conservative politics and focuses on the significance of the revolution that has been sustaining its effect even today.

Key Words: Edmund Burke, 1789 French Revolution, Revolution, Social Change, Tradition.

${ }^{1}$ Doç. Dr., Yüzüncü Y1l Üniversitesi, Edebiyat Fakültesi, Sosyoloji Bölümü

SAD / JSR

Cilt / Volume 20 Say / Number 2 


\section{EDMUND BURKE'UN “FRANSA'DAKİ DEVRİM ÜZERİNE DÜŞÜNCELER” ADLI ESERINIIN SOSYOLOJIKK TAHLILII}

\section{ÖZET}

Hiç şüphesiz ki Batı dünyasını derinden etkileyen ve özellikle Kıta Avrupa'sında tarihsel kırılmalara ve toplumsal değişimlere yol açan en önemli olgulardan birisi, 1789'da Fransa'da gerçekleşen demokratik burjuva devrimidir. Genelde devrimler, özelde de Fransız Devrimine yönelik akademik dünyada gerçekleşen tartışma ve eleştirileri iki taraftan değerlendirmek mümkündür. Bir taraftan, insanlık adına girişilen bu mücadelenin; ilerleme, aydınlanma, insan hakları ve özgürlük adına yapıldığını savunanlar, diğer taraftan, devrimle mülkiyetin ve hakların gasp edildiğini, kadim kurumların ve toplumu bir arada tutan ahlaki ve dini değerlerin ortadan kaldırıldığını ve jakobenizmin ve radikalizmin körüklendiğini iddia edenler. Bu iddia sahiplerinden birisi de, aynı zamanda bu makaleye de konu olan ve yaşadığı dönemde Fransız Devrimine yönelik takındığı sert tutumuyla öne çıkan Edmund Burke'tur. Burke'un devrim hakkındaki düşüncelerini muhafazakâr siyaset açısından ele alan bu makale, günümüze kadar etkisini devam ettiren devrimin toplumlar açısından taşıdığı anlamı üzerinde duracaktır.

Anahtar Kelimeler: Edmund Burke, 1789 Fransız Devrimi, Devrim, Toplumsal Değiş̧im, Gelenek. 


\section{INTRODUCTION}

The French Revolution of 1789, which is one of the turning points of world history, has become one of the most important events that continue to be influential up to today with its secular values and traditional structures and institutions which were eliminated. In addition to the internal dynamics such as economic hardship, social dissatisfaction and inability to meet needs of certain segments of society (Rudê, 2015:19) which facilitated revolution in France, historical developments in the world has also influenced the revolution. The social, political, and class discrimination that have accumulated over the years in continental Europe not only opened the way to revolution but also old regime has lost its power suddenly and buried in the pages of history. When compared to the other revolutions, it can be said that the method the revolution has unique aspects in terms of both methods and results. But this unique aspect of the revolution is not because it established a more democratic and pluralistic regime but because it led to developments that feed more terror, violence and radicalism in society.

The revolution, which has been effected in many regions of the world, in particular in the continental Europe, caused birth of nation-states, spread of nationalist ideologies, and the mass wars in the name of equality and freedom and still continues to be influential. The most important consequence of the revolution in terms of contemporary societies is the change of traditional power and power relations in Europe and afterwards in the world and the emergence of new political actors and regimes in the scene. Today, French Revolution has no doubt great influence for formation of the so-called republics and democracies and absolute destruction of the kingdoms and monarchies.

Perhaps no revolution or revolutionary initiative in history has resulted in heavy consequences for its own society as much as French Revolution. This revolution, which affected almost all world history and politics and reshaped social order, on the one hand disrupted the cliques of the society and on the other hand it has changed the existing regimes and established a new system based on the contract. Thus, the hegemony of 
those institutions which retained the political and economic power in that era, especially aristocracy and the church, has come to an end and a new order led by bourgeois, followed by intellectuals and people has been established. It was the "reason" main basis of revolutionary forces that attempted to build a new society and state based on the philosophy of enlightenment, rationalization and secularism. From this point of view, it is possible to say that, unlike the others before it, the French Revolution constituted foundation cement for both the modernity and the modern world.

In history books, generally contribution of revolution for humanist values, universal law, democracy and individual freedoms are mentioned. However, as in every revolution, as well as achievements and gains of the French Revolution, it has also unforeseeable consequences and losses and it has destroyed traditional structures such as moral and religious values and institutions embodied in these values and the cultural codes and practices that support these structures and it is specified by few people that the revolution harmed consequently the organic constitution of community, which is made up of different components. While those who see themselves on the left side of the ideological spectrum sanctify the revolution, those standing at the right side of the political scale even cannot tolerate the revolution.

In this respect, while the revolution was, according to some people, "a turning point," "main model" of all the revolutions in the history of freedom according to others, the revolution constituted an example for modern totalitarian governments with its central state apparatus and terrorism. The defenders of the French Revolution, nourished from the universe of thought of the Enlightenment and supporting its ideals, greeted the revolution as a movement of liberation / emancipation and progression in a profound ecstasy, drawing attention to its gains, while the couriers were placed in the face of the revolution by drawing attention to its gains opponents emphasize destruction it created / will create (Işı1k 2016: 200).

However, it is a fact that every social change has a price. In other words, if an order is changed by force and deceit, it will have heavy price. 
One of those mostly criticizing the revolution, especially the French Revolution, who has deeply criticized revolution during the period, was the British statesman and political scientist Edmund Burke. Recognized as the father of liberal-conservative politics, Burke tried to warn every segment of the society, especially intellectuals and politicians, predicting what revolution might pave the way for the future in a time when it was popular to praise the revolution. Burke believed that what was experienced was actually an illusion, that the revolutionary myth will soon fail, that the revolution is conceived as a ship lost in the ocean, struggling with the waves and bearing the risk of striking or rocking at any moment and emphasized that revolution would eat his own children beforehand and surrender to Jacobinism.

\section{ARCHEOLOGY OF REVOLUTIONS IN TERMS OF CONSERVATIVE POLITICS}

Conservatism emerged as an ideology and idea that advocates traditional social order resisted pressure of liberalism, socialism and nationalism struggled to return historical monarchy and developed as a reaction to the political and economic changes of the French Revolution at the end of the 18th and 19th centuries. This ideology, opposed to any kind of intervention that can be put on society, especially in the context of reform and revolution, has changed its stance in time depending on changing conditions. While radical conservatives are opposed to all sorts of change, the moderate ones supported changes that are moderate and evolutionary. Ontological bases of conservative thinking were formed of; tradition, pragmatism, incompetence of humankind, organism, hierarchy, authority and ownership (Heywood, 2013: 75-76).

The conservatism that developed as a counterrevolutionary ideology and opposed to more enlightened radicalism and revolutionism developed as an intellectual and political movement in Europe. Conservatism should ultimately be seen as a modern ideology; despite it is against political structure of modernity, philosophy of enlightenment and its radicalism. For him Mannheim defines conservatism as "conscious traditionalism" (Beneton, 1991: 113). Conservative thought should be seen as a consequence of "reactions to the form of constructive rationalist thinking at the center of the idea of enlightenment, practice of 
revolutionary politics embodied in the French Revolution, and revolutionary, utopian socialist movements and of the new social structure shaped after the industrial revolution" (Vural, 2003: 22).

Conservatism is a system of political thought that is cautiously approaching the changes which favor the existing order, cultural accumulation, social gains, traditional and religious values, and the continuation of historical institutions as a whole. The concept of conservation lies at the heart of conservative thinking. Three important factors have influenced the emergence of conservatism as a worldview and a political trend (Ergil, 1986: 1). The first, as emphasized above, is that the ideas of the French Revolution that take down current political regimes and instead domination of the principles of revolution which were criticized by conservatives for being abstract ideas. Second one is the industrial revolution. The revolution, changed traditional production, consumption and division of labor and replaced with mechanization and automation and naturally brings forward continuous change instead of stability in social life. The third one is the enlightenment movement. It is because rationalism (rationalism), which is the basic philosophy of the enlightenment movement, emphasized reason instead of tradition.

These three historical developments took place in continental Europe have been followed with concern by some segments of society as it threatened traditional and social order and envisages the formation of a new society and state. What so-called community opposed was that they believe that the revolution would not only establish a new regime but would abolish values that are indispensable for the society and the individual. Indeed, advocates of conservative thinkers, particularly Burke, Maistre and Bonald, have turned their backs to revolutionary principles, of which guide is abstract ideas, method is violence and oppression, correctness and wisdom unknown for not experienced and obviously aimed at protecting the interests of certain class segments. According to them, the society that is an organic entity is not a structure that can be bent according to the arbitrariness, and it should not be. It is not acceptable to act with a sense of social engineering and try to shape society on the axis of a certain ideology. 
The main concern of the Conservatives is that it is not desirable to sacrifice the historical, social and cultural achievements that have been obtained so far in terms of the individual and society and which protect them against ambiguity and insecurity for a certain ideology. Why do the Conservatives oppose to revolution? Because the conservatives believed that human mind was lacking reason from the ontological point of view and that human beings don't have ability to make their own right decisions and revolutionary projects that centered pure reason would be problematic. Again, according to the conservative idea, people are weak due to nature, morally impaired, selfish, greedy and stigmatized by power. Therefore, there is a need for the existence of a strong state, strong laws and strict punishments for the continuation of the order (Heywood, 2013: 76).

Conservative tradition aimed at protecting society from all kinds of revolutionary transformation projects as an ideological current has opposed the human description of enlightenment rationalism with its "use your own reason" paradigm. In the words of Özipek (2004: 11), " reasoning in epistemological terms can explore the laws of history and society, express law that it must be subject to and a secondary field of activity that will never fail to approve approaches that envisage transforming it in a total way in the direction of a project that can reach the full knowledge required by the ideal world." That is why conservatives don't trust reason much and they have embraced the religion because it brought society together in a common belief.

The conservatives, who managed to protect the prudent stance against change and opposed the erosion of traditional institutions and values, favored stability against change. Because, according to them, what is tried is always safer than what is not tried. Innovation can lead to destructive outcomes because its results cannot be predicted. So "stability is more profitable than innovation; Precision is more valuable than speculation; known is more appreciable than perfection; a known mistake is superior to controversial truth; disease can be more tolerable than treatment; satisfaction of the expectation is more important than whether expectation itself is 'fair'; tendency to be conservative would be more appropriate than any other tendency 
(Oakeshott, 1975:33, cited in Özipek, 2004:91-92) or "It is preferable to be underestimated by being overly anxious and ill-tempered than being destroyed by too much safety" with Burke's words (2016:27).

Conservatives oppose any intervention, initiative or action that may or may not lead to instability and insecurity, since they believe that these are the most important social values that sustain a stable and trustworthy society. Instead of change it under conservatism's concerns for revolution lies the fact that the consequences of revolution that will change many things cannot be predicted. Conservatives believe that it would not be a smart work to perform anything with pure reason only because they are suspicious about the way of founding reason is safe. For him, the revolution, in a paradoxical way, includes ambiguity and insecurity, as well as the ideal of freedom and equality with self-confidence.

Some conservatives, such as Burke, who shared the general belief that change is inevitable, have supported a more moderate or flexible attitude. In contrast to the radical conservatives who oppose every kind of change in principle, the moderates who consider that what are important are not the change itself but the source and form of change supported acceptance of a prudent and cautious change instead of rejection of change in total. According to them, society will change in its stream and in its natural flow. It is not right to try to prevent it or hinder its flow. It is also not possible that such an initiative to be succeed. What is to be done is to give consent to evolutionary change that is to leave society in its own flow and to wait for society to renew itself according to its own needs over time.

Revolutionary changes, however, both demolish the structure of the social order and direct society to unknown, untested and unpredictable uncertainties that cannot even be foreseen. Since it is decided that inadequate reason cannot be a sufficient guide in this process, it is thought that revolutionary projects will lead to devastating consequences. According to Burke, the revolution, which terminates the old regime and apply idealized values instead and thus to lead to the establishment of a healthier society contained demands contradictory to human nature. Any revolutionary-minded discourses which sanctify, divine human and 
claim that man can solve everything with his own reason will soon be falsified. What is to be done is not to drag people into ambiguity, but to try to ensure that the human maintains his own reality and the existing order with wisdom of the past.

\section{CHANGE FROM THE PERSPECTIVE OF CONSERVATIVE IDEOLOGY}

Change and conservatism have been a subject that has been constantly discussed up until today. Conservatism has been perceived as a sectarian and closed form of thought opposing to all forms of change. However, in reality while requests conservation of structures, institutions and values that nourish the existing dominant system in societies at the same time winks at the changeability of the system in question. Although in some radical conservatives, an anti-change attitude can be observed, it should be seen as an exceptional case. It is because change is the law of nature, and no one can stand against this law.

The question to be asked here is what kinds of a change model conservatism requests. A wide range of conservative thinkers including Burke have accepted the change that arises in a self-fulfilling order gradually. What the thinkers are opposed to is not the change but how change is carried out. In this context conservative thinking has been ignoring desires of revolutionary change because it involves violence in all sorts of social engineering practices, plans that produce abstract solutions to social problems, untried ideas and sudden changes.

Conservatives who insist on necessity of being cautious about change, have approved a moderate and reasonable change away from the ideological content which is not realized by the influence of a certain mass, which is not at extreme levels, considering that the structural institutions can change by their internal dynamics. The conservatism, which is basically anti-modern and fostered by a reaction against the French Revolution, undoubtedly has not developed independently of the conditions of the relevant period.

Conservative doctrine was born counter-revolutionary. Since the beginning, it has not only rejected the principles laid out by the French Revolution, but also opposed enlightenment, human rights, and more 
generally the modern political project. "Burke if it is forced by history to be effective, if it is allured by help of historical legacy it is because it thinks that the end of a world ruled by values that are so high for it already arrived. Burke, from time to time, not only condemned the ideological policies of the French revolutionaries with his strong rhetoric of hopeless accent, but offered an in-depth first thought about what would become one of the dominant themes of the 19th century social and political thought. The contrast between traditional social order and modern social order" (Beneton, 1991: 11-12)

In his essay Reflections on the Revolution in France, Burke opposed the basic principles and practices of the French Revolution. In this work, which is trying to criticize the revolutionary rush, Burke did not accept the notion that the French revolution in particular broke the chain of history and cut off the society in time. But Burke, as emphasized above, is not generally against all the revolutions. He will even say that sometimes there is an extraordinary and impressive aspect of the French Revolution. For example, he admired the British revolution. Because, according to him, this revolution has empowered someone else instead of a dynasty, and in fact it has not changed anything. In fact, the revolution has restored the old regime that has begun to decay, has reestablished the trust of the people in governance, and therefore has not brought about a new form of sovereignty. For him, this revolution had to be applauded.

That the British revolution does not to carry a new political order or even support the current constitutional order ensured British people to support the revolution. The revolution has not touched the social, economic, political and cultural structure of the British society, nor has it forced a new scheme into society. On the contrary, as existing institutions have been preserved, the values that hold British society together have become even stronger. The revolution was libertarian because it provided continuity of history, preservation of institutional structures, and continued cultural and political heritage of the more vigorous British people.

Although Burke has shown an anti-revolutionary attitude, it can be said that he occasionally possesses a grip which leads him to a liberal direction and a moderate approach. Because Burke has never advocated 
radical conservatism, he has tried to point out the wrongness of radicalism and revolution. For him, the most dangerous ideas for the societies are the ideas that part the values that hold society together until that day. These ideas usually carry a romantic content. What is essential is not to get abstract and theoretical principles that totally abandon what is present, nor to close all the doors to protect the dominant order. In other words, it can survive if it is protected by the legacy of civilization. Yet revolutionary reason triggers a moral and humanitarian crisis by responding to practices involving fanaticism and violence.

Burke, known for his opposition to revolution, has tried to criticize the revolution in his works. This criticism does not reinforce the idea that he is against revolutionaries and therefore does not accept the revolutions at all. Burke emphasizes the historical continuity he expressed as "real development potentials" against the abstract constitutional order, in response to the negative experiences of the revolution from one side. On the other hand, the new manifestation of modernity and revolutionary political thought is not denied in principle, but on the contrary, it reinterprets itself in the form of a producer in the direction of his own thinking "(Onur-İnce, 2010: 74). In other words, what Burke is trying to do is that the principles and practices that force the society to change do not go through a certain ideological axis and do not have abstract thoughts involving social engineering projects.

According to Burke, change is inevitable because societies are not stable and are all in process of change. This change cannot be prevented. The important thing is not to interfere direction of change, speed and route. Indeed, when the social internal dynamics are clogged and become conservative, they must be prevented from clogging in such a way as not to damage the basic structures and institutional functioning of the society. As a matter of fact, Burke evaluates the American and British Revolutions in this context and praised such revolutionary liberation. In this sense, it is not possible to reduce the revolutions to a concentration of violence or to the sum of institutions. The revolution rests on a project for another world 
that is perceived and understood before it is built, and for this reason it must be resolved both in collective mental designs and in its actions "(Decoufle, 1991: 25).

\section{EDMUND BURKE'S IDEAS ABOUT THE FRENCH REVOLUTION}

Edmund Burke is a politician and statesman who has been a deputy in England for many years. The philosopher is also known as author and orator. He gained reputation for his critics about French Revolution and has opposed the rationalism of enlightenment and the radicalism of revolution. Fundamental concern of Burke, known as the father of Anglo-American conservatism with his stubborn attitude towards revolutionary projects, was actually to prevent attempts called revolution and targeted to destroy social dynamics, to remove the existing political and economic order and to eliminate traditional and religious experience for the sake of abstract ideas.

Burke's practical political stance, who has works from philosophical politics to aesthetics and art, has emerged with his harsh criticism against revolutions especially the French Revolution. Burke, at the same time, has evaluated any kind of change that has been carried out and the concept of "progress" and "development" cautiously. Burke has a liberal identity as well as a conservative one. In fact, what he opposed is not the idea of change itself. On the contrary, he said that it is not possible to prevent idea of change and that the changes that societies undergo during the historical process are inevitable. What he cannot admit is revolutionary traits of change.

That is why, according to Burke (2016: 57), "whether it is right or not, the revolution is the last resort for thinkers and good people to apply." Because the revolutions are movements that carry the soul of innovation and when flows like a flood destroys everything. The ideologues that invite the masses to the streets will drag society to the edge of the abyss because they cannot move with reason. The rebellions allegedly made in the name of society will ultimately lead to revolts and chaos, which will threaten public order. Therefore, 
according to Burke (2016: 60), the spirit of innovation is "in general a result of selfish mood and narrow views." People never desire a future generation who does not look back at their ancestors.

Burke defines revolutions as non-moral initiatives aimed at overthrowing the present order by the use of force. Burke evaluates the power created by revolution as the glory arising from tyranny because of infinity of human will, and he defines revolutionaries as very arrogant, passionate, bearing hatred against the past and hating the aristocracy and the law. (Akkaş, 2004: 173-178). According to him, revolutions have nothing to do with freedom. If they had any relation, or "if they secured freedom only by weakening the government that governs them and by endangering the activities carried out by the government or if they believed that there is no better way out of social commotion against arbitrary governance our ancestors would be renowned as the wise men of the Revolution" (Burke, 2016: 55).

Burke believes that the revolutionary project, which is the sum of abstract and utopian ideas, is merely a fiction and it is impossible to realize the goals set out by revolution and specifies his ideas about this issue as following. "Instead of the monarchic government, bring a government founded by the people's votes, recognize "natural" rights such as" freedom, property, security and uprising against oppression", organize our society in a way that will benefit everyone, wars will end and we will all live happily and prosperously." Therefore, Burke tells us that this is a simple thought -correctly-impossible to be real and came out of an artificial mind shocking human being" (Cameron, 1995:103). Because, according to Burke, the revolutionaries are swimming in the cloudy waters, trusting rhetoric that is pleasant to the ears and actually trying to make society sleep by imposing idea of idealized order.

Burke (2016: 26), compared the revolution to foggy misty winter twilight, and argues that neither in such weather nor at such time we cannot go out. Because, according to him, "wild gas, cloudy weather, is clearly mysterious; but before we get to a judgment, we should expect to see something deep inside, beyond the agitation of the water, dampening of the water, deepening of the first waves. However, moments of 
revolution are moments in which no one is certain of ontological safety, where property and liberty are in jeopardy and no one trusts anyone. In this environment of insecurity, people who are passionate, hateful will try to destroy what is keeping society alive and remove the idea of order.

Burke (2016: 50) believed or wanted to believe that England would not be affected by events in France. According to him, "the people of England will not imitate the traditions which they have never experienced before and will turn back to traditions that do not bring anything other than harm. Our people see practice of the system of dynasty for throne not wrong, but a right thing; not as an affliction but as a profitable works; not as a sign of slavery, but as an assurance of freedom. The people of England think that the roof of the nation has an invaluable value, and perceives throne without interruption as a commitment to stability and our constitution."

Burke said that the revolution would have catastrophic consequences for France, but even if it will not affect Britain, it threatened to leap to other countries. That is why he has rejected the revolution with all his strength and cursed it. However, according to Cameron (1995: 94), Burke seems "almost uncomfortable with the social facts that partially or wholly justified the revolution. The nobles, who retain their privileges, while their functions were taken from their hands, exploited the people in the countryside in an overwhelming misery; hardworking middle class, who carries the heavy burden of taxes, were kept away from the responsible positions of state and incompetent and stupid politics of the governments that come after each other. Burke turns his back to all these. With Thomas Paine's famous statement at that time who gave the best response to Burke's book "Burke pierced not to deceased bird but to its plucked hair".

Nevertheless, Burke stated that there would be no justification for the revolution, and he believed that the administration should be compassionate and fair to the people. The important thing is to govern the country in a constitutional commitment. To discriminate among different sections of the society or to favor certain sections may cause internal mess and confusion because it will damage the sense of justice in society. To 
prevent this, be it tax or services everyone should be treated equally. Burke believes that trying to equalize society or to act in this direction will only cause the natural order to be deteriorated and Burke thinks that such a situation would actually put an extra burden on the building called the community by building up a structure on air that should have been on the ground (Burke, 2016: 79).

Describing the French Revolution as the most horrific event of human history, Burke said that the most distinctive feature of the revolution is Jacobinism that is threatening the traditional way of life by attacking existing institutions destroying institutional structures, as an unreliable form of thought that seizes property and puts abstract political ideas in place of moral values. Indeed, events took place between July 14, 1789, when the revolution took place, July 27, 1794, when Robespierre and Jacobin leaders were sentenced to death in France between confirms Burke's prophecy. These five years with the definition of Timur (2016: 328-329) "have been the years when the people have risen in order to practice supreme ideals that mankind can conceive up to that moment, and on the other hand when revolutionaries have been sentenced to death without hesitation for these ideals. At that time, civil war, foreign war, famine and betrayals all brought doubt on one another. What Robespierre called "despotism of freedom" was also the product of this environment."

It is possible to collect Burke's critique of the French Revolution at two points (Duman, 2010: 276-285). The first is that the revolution was made against two unifying elements of European civilization, namely the nobility (knighthood) and the dynasty. The Revolution was made for the system of values which ultimately became destructive and sometimes radicalizing, ultimately to the West's history, tradition, and cultural heritage, social and political order. Second, the revolution is contrary to the structure and functioning of human nature. It is because the revolution is a rebellion against the natural feelings and passions of man. It contains utopian scheme, guided by universal and abstract ideas and incomplete reason. 
On the one hand, however, Burke criticizes the British and American revolutions for liberal demands and gains, and on the other hand, criticizes French revolution for leading to despotism, terrorism and violence, and thus shifting away from the natural cycle to an asymmetrical position (Ceylan, 2007: 40). Because, in Burke's (2016: 29) words French Revolution, " is out of nature in this intertwined and wildly woven strange chaos; all kinds of crime appear to have spread thousand kinds of theater scene. While watching this horrible tragicomic scene, opposing passions necessarily follow each other; from time to time they are intermingled in our minds; anger after humiliation; Tears after laughter; Fear after disdain"

According to Edmund Burke (2016: 66) in the revolution, "the laws were taken down; courts collapsed; industry was weak without strength; trade ended; salaries have not been paid; finally the public became poorer; church was looted; state could not prospered; constitution of the kingdom, grasped by civil and military anarchy; Everything that was human and divine was sacrificed for the so-called public reputation; As a result, national bankruptcy followed" Burke (2016: 65). Then he will turn and tell the people and the revolutionaries that: "Calculate the gains you have achieved; See what you gained with extravagant and daring ideas of your rulers who teach all their successors and contemporaries to humiliate themselves. France has paid a price which is much higher than what other nations have paid by many nations by following this way! France has reached poverty through crime! France has not sacrificed virtue to its interests maybe, but it has abandoned its interests as well, as France made its virtue as a common property." 


\section{CONCLUSION}

The French Revolution is one of the most important events that undoubtedly lead to a rupture in world history and radically changed the social order. In the formation of the revolution, as well as the displeasure of the French people, world-historical developments have also been influential. The revolution caused concepts such as the destruction of absolute kingdoms, establishment of nation-states in the axis of nationalism ideology, equality, freedom and justice, establishment of democratic and pluralist regimes based on individual rights and universal rules of law, a series of changes in social and political sphere. The results of the revolution were not only confined to the geography of France, but also to other countries of the world.

The French Revolution brought a series of developments while changing the course of history and led to the emergence of new regimes in politics on the one hand and the loss of sovereignty of the religious authority on the other. The footsteps of the Revolution are still heard, although the two centuries have passed, effect of the changes that was created continues, and its ideal of eliminating traditional social order and putting the idea of reason-based order in its place is still alive. Taken as a whole, it has universal consequences not only in terms of continental Europe, but also in terms of permanent effects it created. The revolution was appraised as a historical turning point in the name of mankind by those who regard it as a symbol of progression and reason and it has also been criticized as it overthrown the present order and destroyed the social fabric, religious and moral values, and thus overthrown the social order.

One of the first critics of the revolution's political rationalization and radicalism was Edmund Burke, who has been a source of inspiration for conservative ideas for over two hundred years and has drawn criticism towards the philosophy of enlightenment and its reason-based world order. The revolution in his social analysis is an undesirable and unlikely phenomenon. It is because Burke thought that the revolution deepened the existing problems as well as the problems of the societies. The criticisms that Burke, as a state 
and politician, usually made to the Revolution, especially to the French Revolution, and the reasons that he put forth in putting these criticisms are still valid for present-day revolutions. 


\section{ÖZET}

İnsanlık tarihinin en önemli özelliği, kendi içinde tekerrür etmekle yetinmeyip, aynı zamanda toplumsal, ekonomik ve kültürel açıdan değişim ve dönüşümü içermesidir. Süreç içinde insanlığı en çok etkileyen şey, toplumsal alanda meydana gelen değişimlerdir. Özellikle sosyal değişim, kimi zaman kendi doğal mecrasında yürürken, kimi zaman da insan tarafından müdahale edilmek suretiyle yönü ve rotası değiştirilebilmektedir. Toplumsal devrimler, söz konusu sosyal değişimin insan ürünü olarak ortaya çıkmasıdır. Toplumsal değişimin insan iradesiyle sekteye uğratılması ya da var olan düzenden başka bir sisteme geçilmesini ifade eden devrimin kökeni, insanlık tarihine kadar götürülebilir. Zira insanlar, tarih boyunca siyasal açıdan örgütlenmeye bağlı ideolojik düzenler kurmuşlardır ve bu düzenlerin savunucuları olduğu gibi, zamanla düzen karşıtı gruplar ve kitlesel tabanc1 hareketler de meydana gelmiştir.

Dünya tarihi bu açıdan düzen ve düzen karşıtı grupların savaşımından ibarettir denilebilir. Mevcut düzenden hoşnut olmayan kesimler, yeni bir düzen kurmak amacıyla kimi zaman isyan etmeye, kimi zaman da kanlı savaşları göze alarak savaşmaya çalışmışlardır. Nitekim belli bir anda ortaya çıkan ve hızlı bir biçimde sosyal yapıyı ve siyasi düzeni alaşağı etmeye dönük girişimlerin en yoğun yaşandığı çağ, binlerce insanın ölümüne ve yarattığı sonuçlarla insanlık tarihini edata alt üst eden 18. Yüzyıldaki devrimler olmuştur. Başta Amerika ve İngiliz devrimleri olmak üzere yaydığı etki ve yarattığı radikal sonuçlar açısından en kapsamlı olanı hiç şüphesiz ki, 1789'da Fransa'da gerçekleşen devrimdir. Fransız Devrimi, bugüne kadar insanlığın görmüş olduğu ve kitlesel düzeyde gerçekleşmiş olan en kanlı devrimdir. Mutlak monarşiyi, kilise egemenliğini, sosyal ve geleneksel yapıyı tümden değiştirip, yeni bir devlet ve toplum modelini öngören devrim; başta insan hakları, eşitlik, özgürlük ve adalet gibi kavramlar olmak üzere evrensel hukuk sistemini, sekülerizmi ve siyasal örgütlenme biçimi olan ulus-devleti yaratmıştır.

Politik sistemi olduğu kadar sosyal ve kültürel yaşamı da değiştirmiş olan Fransız Devrimi, dünya tarihi açısından genellikle olumlanmıştır. Çünkü devrimin, Batı dünyasında egemenliğin halka verildiği, sosyal 
eşitliğin ve bireysel özgürlüğün sağlandığı bir çağa başlangıç oluşturduğuna inanılmıştır. Avrupa tarihinde bir dönüm noktasını teşkil ettiğine inanılan devrim, sonuçları itibariyle büyük kazanımları yanında gelecekte daha büyük felaketlere yol açacak gelişmeleri de barındırdığı, dolayısıyla devrimin düzen kurmak değil, kaos yaratacağını iddia eden tutucu bir kesim de olmuştur. Bu kesimlere tercümanlık yapmış, keskin bir zekâyla Avrupa semalarında dolaşan devrimin ruhuna lanet okumuş olan en tanıdık simalardan birisi de İngiliz siyaset adamı ve filozof Edmund Burke'tur.

Edmund Burke, inanılmaz öngörüsüyle, mükemmel retoriğiyle, güçlü zekasıyla genelde devrimi, özelde de Fransız Devrimini adeta topa tutmuştur. Burke, "Fransız Devrimi Üzerine Düşünceler” adlı kitabında bu eleştirilerini sıralarken devrimi, bir yandan insanlık adına bugüne kadar meydana getirilen, tarihin testinden geçip doğru olduğu kabul edilen ve bireyin sağlam bir zeminde yürümesini sağlayan toplumsal değerleri, diğer yandan birey için olduğu kadar toplum için de elzem olduğuna inanılan din, devlet ve aile başta olmak üzere var olan geleneksel ve kurumsal değerleri yok ettiğine inandığı için eleştirmiştir. Yazar, bu eleştirilerini temelde iki noktada toplamıştır. Birincisi, devrimin ontolojisine, yani ortaya çıkmasının gereksizliğine ve mantıksılı̆ğına değinmiş, ikincisi de, devrimin metrolojisine yani kitlesel düzeyde insanların adeta biri sürü peşine takılarak, birilerinin ütopik, soyut fikirlerinin peşinde koşması ve bunu yaparken de insanlık dışı muamelelerde bulunulması, her tür şiddetin maruz gösterilerek mevcut düzeni ve var olan yapıları ortadan kaldırılmaya çalışılmasıdır. 


\section{REFERENCES}

Akkaş, H. H. (2004). Muhafazakâr Düşünce ve Edmund Burke. Ankara: Kadim Yayınları.

Beneton, P. (1991). Yeni Muhafazakârlık. C. Akalın (Çev.). İstanbul: İletişim Yayınları.

Burke, E. (2016). Fransa'daki Devrim Üzerine Düşünceler. O. Arslan (Çev.). Ankara: Kadim Yayınları. Duman, F. (2010). Aydınlanma Eleştirisinden Devrim Karşıtlığına Edmund Burke. Ankara: Liberte Yayınları.

Cameron, J. M. (1995). Edmund Burke, Batı Düşüncesinde Siyaset Felsefeleri. N. Muallimoğlu (Çev.). İstanbul: Marmara Üniversitesi İlahiyat Fakültesi Vakfı Yayınları.

Ceylan, A. Y. (2007). Edmund Burke’ün "Muhafazakâr” Düşüncesinde "İyi Devrim” "Kötü Devrim” Ayrımı. Muhafazakâr Düşünce Dergisi, 3 (11), 23-43.

Decoufle, A.C. (1991). Devrimler Sosyolojisi. M. Aközer (Çev.). İstanbul: İletişim Yayınları.

Ergil, D. (1986). Muhafazakâr Düşüncenin Temelleri: Muhafazakârlık ve Yeni-Muhafazakârlık. Ankara Siyasal Bilgiler Dergisi, Cilt, 41, Say1, 1, 269-292.

Heywood, A. (2013). Siyaset. B.B.Özipek vd. (Çev.). Ankara: Adres Yayınları.

Iş1k, S. (2016). Devrim ve Düzen: John Locke ve Edmund Burke’te Devrim Düşüncesi. Ankara: Kadim Yayınları.

Onur-İnce, H. (2010). Muhafazakar İdeoloji Din-Siyaset. İstanbul: Alan Yayınc1lık.

Özipek, B.B. (2004). Muhafazakârlık: Akıl, Toplum, Siyaset. Ankara: Liberte Yayınları.

Rudê, G. (2015). Fransız Devrimi. A. İ. Dalgıç (Çev.). İstanbul: İletişim Yayınları.

Timur, T. (2016). Mutlak Monarşi ve Fransız Devrimi. İstanbul: Yordam Yayınları.

Vural, M. (2003). Siyaset Felsefesi Açısından Muhafazakârlık. Ankara: Elis Yayınları. 